\title{
Anxiety, Motivation and Attitude of Indian Students in Learning English in National-Type Tamil Schools
}

\author{
Sinusha Murthy ${ }^{1}$ \& Kee Jiar Yeo ${ }^{1}$ \\ ${ }^{1}$ Faculty of Education, University Technology Malaysia, Johor, Malaysia \\ Correspondence: Sinusha Murthy, Faculty of Education, University Technology Malaysia, Johor, Malaysia. Tel: \\ 60-107-054-031. E-mail: sinushamurthy@gmail.com
}

Received: August 1, 2018

doi:10.5539/ass.v14n11p1
Accepted: September 1, $2018 \quad$ Online Published: October 22, 2018

URL: https://doi.org/10.5539/ass.v14n11p1

\begin{abstract}
The aim of this study was to determine the students' anxiety, motivation and attitude in learning English based on their socioeconomic status and English language achievement in National-type Tamil schools. Samples for this study comprised of 144 year 5 Indian students from four Tamil schools. Data for this study were collected by questionnaire adapted from instruments by Tsai \& Chang (2013), Ghazvini \& Khajehpour (2011) and Gaur (1985). The findings of this study showed that Indian students from urban and rural areas have a moderate level of anxiety in learning English. Students from both areas were instrumentally motivated and showed positive attitudes towards learning English. However, negative correlations were identified between English Language achievement and level of motivation in learning English as well as between daily spoken languages at home and with friends and the level of English language achievement. The result of this study also illustrated that level of motivation and attitude are positively correlated. In conclusion, the samples of this study showed high levels of anxiety as well as motivation and attitude in learning English. It is recommended that future research take more samples and include qualitative data to increase the reliability of the study.
\end{abstract}

Keywords: anxiety, motivation, attitude, socioeconomic status (SES), English language, national-type Tamil schools

\section{Introduction}

English is known as an international language. English language has being used as a tool of communication on a wide scale all over the world. English was introduced in the Malaysian Education system since early nineteen century, when British colonists rule this country. After independence, the education system in Malaysia faced a big evolution. Since independence, Bahasa Malaysia (Malay Language) has been authorized as the National Language and English became the second language of this country (Gill, 2002). English has become one of the compulsory subjects taught in all schools in Malaysia. English language helps the learners not only to excel in their studies but also help them to provide better and secure jobs (Morshidi et al., 2004).

However, learning a second language or a foreign language is not an easy task for many people and it can be a stressful task for certain learners. Learning a second language can create a kind of negative emotional arousal, worrying and nervousness which is known as foreign language anxiety or second language anxiety (MacIntyre, 1998). Language anxiety is one of the great obstacles in learning a second language. A study has also proven that anxiety prevents second language learners from achieving a high level of proficiency in the specific language and provides a negative effect to the learners (Aida, 1994).

Besides language anxiety, there are other factors that may affect language learners learn a second language that is motivation and attitude. Motivation and attitude are two key components in socio-educational model of second language acquisition proposed by Gardner (1985). Motivation and attitude are strongly related to each other. For the past few decades, motivation has been a hot topic in the area of experiential research within the context of learning a foreign language or second language. Gardner (1985) derived motivation as ones strive to acquire a language to fulfil their desire and self-satisfaction. Motivation becomes the key force for a language learner to learn a second language.

Besides the roles anxiety, motivation and attitudes, socioeconomic status also plays an effective role in learning English as a second language. Fan (2011) identified that socioeconomic status not only affects students language 
proficiency and achievement, however, shows a strong influence on motivation to learn, self-regulation and students' self-related beliefs. The importance of socio-cultural factors in learning second language also have been emphasized by Gardner (1985) that parental encouragement and praise on students' can motivate students' behavior to learn a second language. Moreover, in a non-native English speaking community, students are rarely exposed to communicate in English and they more prefer to communicate using their mother tongue or their first language more efficiently (Sirin, 2005).

There are vast differences in the situation and lifestyle of urban and rural areas students' family backgrounds. Students' from rural areas who are from poor SES families are preoccupied with basic necessities and they have only limited access to English language (Yuet, 2008). There are several studies illustrated that learners from low SES backgrounds have low motivation and aspirations on education and language learning (Sung \& Padilla, 1998; Ghani, 2003; Malini, 2015). Students' from high family income, acquire higher levels of proficiency in English compared to students in lower income community (Shamim, 2011).

There were several researches on learning the English language as a second language in Malaysia however, there were limited research studies were done on the three variables which are anxiety, motivation and attitude. There was a lack of attention were given by the researchers and teachers on the effects and the influences of these three variables in learning English by a second language learner.

On the other hand, there were also very few research studies were conducted in Tamil primary schools, SJK (T). It is known that the Indian community in Malaysia is the minority community and research study on the Indian community in Malaysia is, very few especially for learning English as a second language. A few research studies only concern about the curriculum activities conducted in Tamil primary school and very little focus is given to Indian students. Besides, studies on SES of Indian community in rural and urban areas had not been given much concern by researchers. Moreover, there were less evidence of Indian students on their level of anxiety, motivation and attitudes in learning English and their English language achievements.

There were several studies covered on anxiety, motivation and attitude towards learning English as second language, however the limited study is devoted towards Indian students in Malaysia based on their socioeconomic status. Thus, this research study is meant to fill up the research gap which involves the Tamil primary school students and their English language performances.

\subsection{Literature Review}

Four theories underpin the current study, namely Horwitz, Horwitz and Cope's Theory of Foreign Language Anxiety (Horwitz, 1986) and Gardner's Theory (Socio-Educational Model) (Gardner, 1985).

Foreign language anxiety, or second language anxiety has been attracting several researchers in the field of educational psychology and foreign language education. Literally, anxiety has been categorized into three types of anxiety which are trait, situation-specific and state anxiety (MacIntyre \& Gardner, 1989). Later on after many researches, language anxiety, researchers comes to a conclusion that foreign language anxiety is a situation-specific anxiety and the researchers who discover it with their theoretical model is Horwitz, Horwitz and Cope's (1986). Foreign language anxiety was defined as "a distinct complex of self-perceptions, beliefs, feelings and behaviors related to classroom language learning arising from the uniqueness of the language learning process" (p. 128) by Horwitz et al. (1986).

Horwitz, Horwitz and Cope's Theory of foreign language anxiety has become one of the most influential theories that been using by foreign language and second language anxiety researchers. Horwitz, et al. (1986) creates a theoretical model of language anxiety by concerning on the performance evaluation within an academic and social context. They find out that there are relationship between foreign language anxiety and three performance related anxieties which are text anxiety, communication apprehension and fear of negative evaluation.

Gardner (2001) states, that motivation is an important element in language aptitude which able to determine the success of a language learner in acquiring a second language in a classroom setting. Motivation is a trigger for students to learn a foreign language or a second language in a classroom and without motivation, students will be failing to put good effort and much desire to learn English as a second language. Goal orientated motivation and core motivation are two levels of motivation in Gardner's model (Gardner, 1993). The formation of goals in motivation includes the student's core motivation, student's orientation to language learning and the student's attitudes towards the learning situation. Thus, according to Gardner (1993), highly motivated students will have the effort and courage to learn the language with enjoy and strive to achieve their goals in learning a second language.

There are numerous researches show that the ability of students to acquire a second language not only based on 
students' motivation, mental competence or language skills but also students' attitude towards learning a second language plays an important role (Baker, 1992). Attitudes can acts as a crucial element in language growth or destruction depends on the degree of positive or negative reaction towards learning a second language. Gardner's (1979), socioeducational model which consists of four segments such as social milieu, individual differences, second language acquisition contexts and outcomes. The concept of social milieu construct by Gardner (1979) contains variables such as intelligence, language aptitude, motivation and situational anxiety which are closely interrelated with the context and outcomes of the second language learning. This model was further modified by Gardner (1985) by introducing the concept of integrative motive within the individual differences variable and divided it into two components which are attitudes toward the learning situation and integrativeness.

This current study will focus on one of the variables from Gardner's socio-educational model (1985) which is attitudes towards the learning situation. Attitudes towards the learning situation of Gardner (1985), involve attitudes of students towards the school, reactions to the textbooks, evaluation of the language teacher and the language courses. Besides, this model also illustrates that the nature of the learning situation influences student's attitude and motivation. According to Gardner (1985), motivation comes from one's attitude and to measure the variables in socio-educational models, Gardner creates Attitude and Motivation Test Battery (AMTB) (Shams, 2008).

\subsection{Objective}

The current study involved Indian students from National-type Tamil school. The study was aimed to:

1. Determine the level of anxiety, motivation and attitude in learning English Language between Indian students from urban and rural areas National-type Tamil School (SJKT).

2. Investigate any significant differences in the level of anxiety, motivation and attitude in learning English Language between Indian students from urban and rural areas National-type Tamil School (SJKT).

3. Determine any significant relationship between socioeconomic status (SES) and the level of anxiety, motivation and attitude in learning English among Indian students in National-type Tamil School (SJKT).

4. Investigate any significant relationship between English Language achievement and the level of anxiety, motivation, attitude in learning English Language among Indian students from National-type Tamil School (SJKT).

5. Determine any significant relationship between socioeconomic status (SES) and English Language achievement among Indian students in National-type Tamil School (SJKT).

6. Investigate any significant relationship between anxiety, motivation and attitude of Indian students in learning English.

\section{Method}

This study was conducted to determine Indian students' anxiety, motivation and attitude in learning English based on their socioeconomic status and English language achievement. This study was conducted at four different schools from two different backgrounds of area density which are urban and rural areas at Kluang, Johor. Three schools were selected from rural areas and one school from urban area. The respondents of this study are year 5 Indian students from the selected Tamil schools and the total number of respondents of this study is 144 respondents.

A questionnaire was designed to fulfill the objectives of this study. The questionnaire constructs were adapted from three instruments on four main variables which are anxiety, motivation, attitude and socioeconomic status. The anxiety construct was adapted from a study by Tsai \& Chang (2013). Tsai \& Chang (2013) adapted 24 items from the Foreign Language Classroom Anxiety Scale (FLCAS) which consists of 33 items created by Horwitz et al. (1986) which Cronbach's alpha was .84. According to the current research questions, 10 items which are able to measure anxiety in three dimensions which are (1) anxiety in using English, (2) English test anxiety, and (3) English language class anxiety were selected from the Foreign Language Classroom Anxiety Scale (Tsai \& Chang, 2013).

The constructs of motivation and attitude were adopted from a study by Ghazvini \& Khajehpour (2011). The Gardner's Attitude and Motivation Test Battery (AMTB) was adapted and modified by Ghazvini \& Khajehpour (2011) and the Cronbach's Alpha of the modified questionnaire was 0.7. Ghazvini \& Khajehpour's (2011) questionnaire consisted of 40 items. There are 20 items on the attitudes of students (positive and negative attitudes) and 20 items on motivational orientation (instrumental and integrative).

The questionnaire of this study consists of 60 items and was measured using the 5-point Likert scale which 
ranges from "strongly disagree" to "strongly agree". According to the result of a pilot test of this study, the Alpha value of the variables of anxiety towards learning English was 0.713, variables of motivation towards learning English was 0.768 and variables of attitude towards learning English was 0.741 . The reliability result showed that all the items of the questionnaire of this study are reliable and suitable for this current research study.

The data contained in the questionnaires were analysed using the Statistical Package for Social Science (SPSS) software version 16.0. Both descriptive analysis and inferential analysis were conducted to fulfill the requirements of the objectives. Descriptive analysis was used to analyse the respondents' demographic data in Section A in terms of percentage and frequency. As for data in Section B, Section C and Section D were analysed using inferential analysis, such as using the independent-sample T-test, Pearson product moment correlation coefficient and Spearman's rank correlation coefficient.

\section{Result and Discussion}

Based on the descriptive statistical analysis, it was found that there were total 72 students from urban areas and 72 students from rural area. There were total 74 male students and 38 students from rural areas and 36 students from urban areas while there were total 70 female students and 34 female students from rural areas and 36 students from urban area respectively.

As for the distribution of the respondent according to the daily spoken language at home, there were 129 respondents daily spoken language is Tamil language and 66 of them are from rural areas and 63 of them from urban area. There were only one respondent spoke in English daily at home in rural areas while there were 5 respondents spoke in English daily at home. The distribution on the daily spoken language with friends showed that there were 60 respondents from urban area and 58 respondents from rural areas spoke in Tamil with their friends while there are only 4 students in urban and rural respectively spoke in English to their friends.

The distribution of respondents based on last English Test result illustrated that majority of students about 29 of them from rural areas and 25 of them from urban area scored C (50-59) for their last English test. However the number of respondents who scored A (80-100) is higher in urban area that is about 16 respondents compared to rural area, only 6 respondents. As for the distribution of respondents' parents' educational background, the majority of the respondents' parents were educated until SPM level which is 27 of them from rural areas and 37 of them from urban area. There are only 2 respondents' parents' were educated until UPSR in urban area while there are 15 respondents' parents were educated until UPSR in rural area.

The distribution of respondents' parents' occupation showed that there were total 29 of the respondents' parents are working in professional sectors which are 10 of them from urban area and 19 of them from rural areas. While, there are 115 of the respondents' parents are working in non-professional sectors which are 53 of them from urban area and 62 of them from rural areas. Besides, based on the distribution of the salary, majority of urban area parents' salary is about rm1500-2500 while the majority of rural area parents' salary is about rm500-1500.

The level of anxiety in learning English language among Indian students were analysed and the overall mean and standard deviation are 2.89 and 0.58 respectively. The overall mean value of the level of anxiety showed a moderate level however urban area students faced high level of anxiety compared to rural area students. This result is in contrast with the findings of Khattak et al. (2011) which stated that poor socioeconomic background may lead to anxiety in learning the English language. The level of anxiety was analysed based on three aspects which are English test anxiety, anxiety in using English and English classroom anxiety. The results show that among the three aspects, the highest mean value was scored by English test anxiety which is about 3.27. This can be concluded that students feel more anxious to face English test because they are worried about the consequences of failing in English test. This finding correlates with Humphries' (2011) which said that students' levels of achievement suffer when students get nervous to attend English class, English test and to communicate in English.

The level of motivation in learning English language among Indian students were analysed and the overall mean and standard deviation are 3.69 and 0.69 respectively. This result shows that the students' facing a good level of motivation in learning English language, however, by comparing both the school areas, students' from urban areas states high level of motivation compared to rural area students. However, the students from the both areas are highly instrumentally motivated towards learning English language because they learn English for future career, education and to improve their self-respect. This result is similiar with the findings of Rahimah et al. (2004) and Ler (2012) which showed that parents in rural areas do not pay much attention to their children's level of English proficiency and academic achievement, and this leads to low levels of motivation in rural area students. 
There are two type of attitudes which are positive attitude and negative attitude. In positive attitude, among the four aspects, the highest mean value was scored by the second aspect which is "Expression of the Desire to Improve English" with a mean value of 3.82. The item "I plan to learn as much English as possible" scored the highest mean value for this aspect at 3.95. However, when comparing the urban and rural areas, the mean value for students from the urban areas was higher than for students from rural areas. These findings are supported by Mattheoudakis and Alexiou's (2009) paper which stated that high socioeconomic background students are lucky enough to get a better education environment and better surroundings which would encourage them to improve their English language proficiency as much as they want compared to low socioeconomic students.

In negative attitude, the item "I prefer to read materials in other languages rather than English" scored the highest mean value for this aspect at 3.54. However, when comparing urban and rural areas, the mean value for students from rural areas was higher than for students from urban areas. This can be explained by Aiken and Barbarin (2008) whose paper concluded that students from low SES background acquire low language skills, exhibit slow letter recognition and phonological awareness, and also face difficulties in reading.

The data analysis on the differences in the level of anxiety, motivation and attitudes of Indian students between urban and rural areas were done using Independent-sample t-test. The results showed there was no significant differences in the level of anxiety, motivation and attitudes of Indian students between urban and rural areas National-type Tamil School in learning English Language. This can be because the mean values for each variable showed only slight differences between urban and rural areas. Therefore, the hypotheses $\mathrm{H}_{0} 1, \mathrm{H}_{0} 2$ and $\mathrm{H}_{0} 3$ were accepted.

The next data analysis were done to determine the relationship between socioeconomic status (SES) and the level of anxiety, motivation and attitude in learning English among Indian students in National-type Tamil Schools, the data were analyzed using Spearman's rank-order correlation coefficient. There is no significant relationship between socioeconomic status (SES) and the level of anxiety, motivation and attitude of Indian students in learning English Language.

To investigate the relationship between English Language achievement and the level of anxiety, motivation and attitude in learning English among Indian students in National-type Tamil Schools, the data were analyzed using Pearson-Correlation test. The relationship between socioeconomic status (SES) and the level of motivation among Indian students in learning English Language showed a significant negative correlation however there is no any significant correlation relationship between English language achievement and the level of anxiety of Indian students in learning English language and there is no any significant correlation relationship between English language achievement and the level of attitude of Indian students in learning English language.

To determine the relationship between socioeconomic status (SES) and English language achievement of Indian students in National-type Tamil Schools, the data were analyzed using Spearman's rank-order correlation test. The result showed that the variables (parents' highest level of education, daily communication language at home and with friends) and English language achievement were negatively correlated to each other. While, there were no significant correlation between the variables (parents' occupation and parents salary) and English language achievement.

Lastly, to investigate the significant relationship between anxiety, motivation and attitude of Indian students in learning English, the Pearson- Correlation test was applied. The data were analyzed according to (1) the relationship between Anxiety and Motivation of Indian students in learning English Language, (2) the relationship between Anxiety and Attitude of Indian students in learning English Language and (3) the relationship between Motivation and Attitude of Indian students in learning English Language. The results revealed that there was only a significant positive correlation on the relationship between motivation and attitude of Indian students in learning English Language. This finding is agreed upon by several researchers such as Al-Tamimi \& Shuib (2009), Bidin et al. (2009), Ghazvini and Khajehpour (2011), Thang, Ting, \& Jaafar (2011), Conday Ditual (2012), Yang (2012), and Mat and Yunus (2014) who stated that attitude and motivation are positively correlated. Whereas, there was no significant relationship between anxiety and motivation of Indian students in learning English Language and there was no significant relationship between anxiety and attitude of Indian students in learning English Language.

\section{Recommendation}

The research findings helped to find out students' anxiety, motivation and attitude levels in learning English. The findings on students' anxiety levels in learning the English language, the data showed a moderate level of anxiety. However, when comparing both school areas, students from urban areas showed higher levels of anxiety compared to rural area students. Usually, as shown in the study by Khattak et al. (2011), rural students face 
higher levels of anxiety. However, in this research study; urban students faced higher levels of anxiety. This can be because urban students are highly worried about their academic achievement and the consequences of failing their English tests. Thus, to overcome this problem, teachers and parents should encourage their students and children to study English to improve their language skills and not be too exam-oriented.

The findings also revealed that students are more instrumentally motivated to learn English. Students' motivation is very important to improve their interest in learning English as a second language. However, instrumental motivation needs to change to become integrative motivation. This is because instrumental motivation is a form of short-term motivation as students learn English only to fulfill their desired goals. Therefore, it is better to create integrative motivation within the students rather than instrumental motivation. Integrative motivation can be activated in a person when they are interested to learn English in order to get involved in a culture or social context. Thus, to implement this integrative motivation, parents must play a major role at home by communicating in English with their children, while teachers should encourage students to speak in English even by using small words or simple sentences.

The findings illustrated that students have high levels of motivation and positive attitude towards learning English. However, they showed poor performance in their English language achievement. This is very critical as there may be other external attributes that affect students' performance in English. According to Galloway (2011), there are a number of factors which influence students in acquiring the English language such as their motivation for learning English, attitudes towards the varieties of English and attitudes towards English teachers. It shows that English teachers' attitudes are also an important factor in influencing students' English academic achievement. Teachers should feel more committed and involved in teaching the English language in the classroom. Teachers should be prepared with lots of creative games and techniques that can help students to understand the English language more easily so that the students will feel happy to learn English. These fun learning techniques indirectly help students be involved in learning the English language and improve their language skills while helping them improve their English language achievements too.

In this 21st century, the implementation of KSSR and KSSM in the school curriculum by the Ministry of Education has helped teachers improve their teaching strategies. The arrangement of tables and classroom settings according to the 21 st century learning style is helpful for teachers to conduct group activities and discussions easily and effectively. Teachers must improve their teaching skills by using technology in their lessons. There are a number of helpful websites such as VLE Frog which can be used to give students extra-curriculum activities, and KAHOOT and QUIZZES which can help teachers conduct quizzes. Besides this, they also can use the "Tarsia" and "Eclipse Crossword" applications to create hands-on educational games in the classroom.

Besides, it is recommended that future researcher to take more samples and include qualitative data to increase the reliability of the study.

\section{Conclusion}

This study was conducted to determine the relationship between anxiety, motivation and attitude levels of Indian students in learning English in Tamil national schools. The results of the study showed that urban students face higher anxiety levels compared to rural area students. In addition, the Indian students included in this study are highly and instrumentally motivated to learn English and they also showed positive attitudes toward learning the English language. There is a strong and positive relationship between motivation and attitude in learning English. However, good levels of motivation and positive attitude do not reflect a good achievement in English. Therefore, teachers, parents and the Ministry of Education should be working on students' English academic achievement by considering these three variables which play an important role in learning the English language. The recommendations based on this research findings serve as helpful tips for educators and parents, while the recommendations for future research will be good guidelines for upcoming researchers.

\section{References}

Aida, Y. (1994). Examination of Horwitz, Horwitz, and Cope's construct of foreign language anxiety: The case of student of Japanese. The Modern Language Journal, 78, 155-168. https://doi.org/10.1111/j.1540-4781. 1994.tb02026.x

Aikens, N. L., \& Barbarin, O. (2008). Socioeconomic differences in reading trajectories: The contribution of family, neighborhood, and school contexts. Journal of Educational Psychology, 100, 235-251. https://doi.org/10.1037/0022-0663.100.2.235

Al-Tamimi, A., \& Shuib, M. (2009). Motivation and Attitudes Towards Learning English: A Study of Petroleum 
Engineering Undergraduates at Hadhramout University of Sciences and Technology. GEMA Online Journal of Language Studies, 9(2), 29-53. Retrieved from http://www.ukm.my/ppbl/Gema/abstract\%20for\%20 pp\%2029_55.pdf

Baker, C. (1992). Attitudes and Language. Clevedon: Multilingual Matters Ltd.

Bidin, S., Jusoff, K., Aziz, N. A., Salleh, M. M., \& Tajudin, T. (2009). Motivation and Attitude in Learning English among UiTM Students in the Northern Region of Malaysia. English Language Teaching, 2(2), 16-20. https://doi.org/10.5539/elt.v2n2p16

Chiu, Y. C. (2008). The Relationship Between Motivation and Achievement in Foreign Language Learning in a Sixth Form College in Hong Kong. Unpublished Doctoral Dissertation, University of Leicester, UK.

Fan, W. (2011). Social influences, school motivation and gender differences: An application of the expectancy-value theory. Educational Psychology Review, 31, 157-175. https://doi.org/10.1080/01443410. 2010.536525

Galloway, N. (2011). An investigation of Japanese university students' attitudes towards English. Unpublished Ph.D. dissertation, University of Southampton, UK.

Gardner, H. (1993). Frames of mind: The theory of multiple intelligences (10 anniversary ed.). New York, NY: Basic Books.

Gardner, R. C. (1979). Social psychological aspects of second language acquisition. In H. Giles, \& R. St. Clair, (Eds.), Language and social psychology (pp. 193-220). Oxford: Basil Blackwell

Gardner, R. C. (1985). Social psychology and second language learning: The role of attitude and motivation. London: Edward Arnold.

Gardner, R. C. (2001). Integrative motivation: Past, present, and future. Distinguished Lecture Series: Temple University Japan.

Ghani, M. (2003). The relationship of socioeconomic status and length/medium of English instruction with individual differences and English proficiency in Pakistan. Journal of Research, 3.

Ghazvini, S. D., \& Khajehpour, M. (2011). Attitudes and motivation in learning English as second language in high school students. Procedia - Social and Behavioral Sciences, 15, 1209-1213. https://doi.org/10.1016/j.sbspro.2011.03.264

Gill, S. K. (2002). International Communication: English Language Challenges for Malaysia. Serdang: Universiti Putra Malaysia Press.

Horwitz, E. K., Horwitz, M. B., \& Cope, J. (1986). Foreign language classroom anxiety. Modern Language Journal, 70(2), 125-132. https://doi.org/10.1111/j.1540-4781.1986.tb05256.x

Humphries, R. (2011). Language Anxiety in International Students: How can it be overcome? Griffith Working Papers in Pragmatics and Intercultural Communication 4(1/2), 65-77.

Khattak, Z. I., Jamshed, T., Ahmad, A., \& Baig, M. N. (2011). An Investigation into the Causes of English Language Learning Anxiety in Students at AWKUM. Procedia - Socialand Behavioral Sciences, 15(0), 1600-1604. https://doi.org/10. 1016/ j.sbspro.2011.03.337

Ler, E. C. (2012). Cultutal Factors Affecting English Proficiency in Rurl Areas. Advances in Language and Literary Studies, 3(1), 245-267. https://doi.org/10.7575/aiac.alls.v.3n.1p.1

MacIntyre, P. D. (1998). Language anxiety: A review of the research for language teachers. In D. J. Young (Ed.), Affect in foreign language and second language learning (pp. 24-45).Boston: McGraw-Hill.

MacIntyre, P. D., \& Gardner, R. C. (1989). Anxiety and second-language learning: Toward a theoretical clarification. Language Learning, 39(2), 251-275. https://doi.org/10.1111/j.1467-1770.1989.tb00423.x

Malini, A. (2015). ESL learning anxiety among tamil primary school students in Sjk (T) Kampar. Universiti Tunku Abdul Rahman.

Mat, S. S. C., \& Yunus, M. M. (2014). Attitudes and Motivation Towards Learning English among FELDA School Students. Australian Journal of Basic and Applied Sciences, 8(5), 1-8. Retrieved from http://ajbasweb.com/old/ajbas/2014/Special 2/1-8.pdf

Mattheoudakis, M., \& Alexiou, T. (2009). Early foreign language instruction in Greece: Socioeconomic factorsand their effect on young learners' language development. In M. Nikolov (Ed.), The age factor and 
earlylanguage learning (Studies on language Acquisition) Language Acquisition) (pp. 227-252). Mouton deGruyter. Nikolov_10_Ch10. Times NRMT 1120 Jiang (SOLA). https://doi.org/10.1515/9783110218 282.227

Shamim, F. (2011). English as the language for development in Pakistan: Issues,challenges and possible solutions. In H. Coleman (Ed.), Dreams and Realities: Developing Countries and the English Language (pp. 291-309). London: British Council. Retrieved from http://www.teachingenglish.org.uk/transform/books/ dreams-realities-developing-countries-english-language

Shams, M. (2008). Students' attitudes, motivation and anxiety towards English language learning. Journal of Research, 2(2), 121-144.

Sirat, M., Bakar, R., Lim Hock Eam dan Mohamed Nasser Katib. (2004). Kajian Pencapaian Akademik dan Kebolehgunaan Tenaga Siswazah di Institusi PengajianTinggi.UniversitiSains Malaysia: Institusi Penyelidikan Pendidikan Tinggi Negara.

Sirin, S. R. (2005). Socioeconomic status and academic achievement: A meta-analytic review of research. Review of Educational Research, 75, 417-453. https://doi.org/10.3102/00346543075003417

Sung, H., \& Padilla, A. M. (1998). Student motivation, parental attitudes, and involvement in the learning of Asian languages in elementary and secondary schools. Modern Language Journal, 82(2), 205-216. https://doi.org/10.1111/j.1540-4781.1998.tb01193.x

Thang, S., Ting, S., \& Jaafar, N. (2011). Attitudes and motivation of Malaysian secondary students towards learning English as a second language: a case study. The Southeast Asian Journal of English Language Studies, 17(1), 40-54. Retrieved from http://journalarticle.ukm.my/2047/

Tsai, C.-C., \& Chang, I.-C. (2013). The Study on Motivation and Anxiety of English Learning of Students At a Taiwan Technical University. International Journal of English Language Teaching, 1(1), 24-41. Retrieved from http://www.eajournals.org/wp-content/uploads/TheStudy-on-Motivation-and-Anxiety-of-English-Lear ning-of-Students-at-a-Taiwan-Technical-University.pdf

Wahab, R. A., Sawiran, M. S., Hamid, F. A., \& Ayub, H. (2004). Research on issues pertaining to the teaching of English in FELDA schools in Segamat. Retrieved from http://eprints.uitm.edu.my/1910/

Yang, X. (2012). Attitude and Motivation in L2 Learning among UM Master Students. International Journal of Management and Sustainability, 1(1), 13-22. Retrieved from http://www.aessweb.com/pdf-files/ijmspp. 13-22.pdf

\section{Copyrights}

Copyright for this article is retained by the author(s), with first publication rights granted to the journal.

This is an open-access article distributed under the terms and conditions of the Creative Commons Attribution license (http://creativecommons.org/licenses/by/4.0/). 